\title{
セラミックヒーターを用いたポリスチレン 射出成形品のウェルドライン加熱消去
}

\author{
泊 清隆*・原田敏彦*・前川善一郎**・濱田泰以**
}

\section{Elimination of Weldlines in Polystyrene Injection Moldings Using a Ceramic Heater}

\author{
Kiyotaka Tomari*, Toshihiko Harada* \\ Zenichiro MaEKawa**, Hiroyuki Hamada**
}

\begin{abstract}
Polystyrene injection moldings can easily exhibit weldlines which appear as cracks on the surface and which of ten result in serious problems. These cracks develop as a $\mathrm{V}$-notch caused by entrapping air or contaminants at the merging flow fronts. The $\mathrm{V}$-notch not only reduces appearance quality but also mechanical properties, especially for brittle materials such as polystyrene. The V-notch depth was measured to be several microns using surface roughness tester. In our previous study, the weldline area which influences mechanical properties was found to be several hundred microns deep, including the surface V-notch. Preheating of a mold with halogen light or a high frequency inductor can eliminate the weldline efficiently. These methods, however, reduce the safety for work and require long cooling times.

An alternate method for weldline elimination was discussed in the present study, in which a ceramic heater fixed directly on the cavity at the weldline region was heated instantaneously during the injection process. Using this approach, the effects of heating on the appearance and the mechanical properties of polystyrene injection molding with weldlines were clarified.
\end{abstract}

Key wards : Weldline/Polystyrene/Injection molding/Appearance quality/Ceramic heater

\section{1. 緒言}

家電品なぞに用いられるポリスチレンは，射出成形 品中に生じるウェルドラインが明確に表面に現れやす

* 大阪市立工業研究所 プラスチック課

大阪市城東区森之宮 1-6-50（开 536）

Osaka Municipal Technical Research Institute,

1-6-5, OMorinomiya, Joto-ku, Osaka 536 Japan

** 京都工芸繊維大学 䋐維学部

京都市左京区松ヶ崎御所海道町 (

Kyoto Institute of Technology

Matsugasaki, Sakyo-ku, Kyoto 606 Japan

1992.3.16 受理
い材料の一つである. ウェルドラインが割れと同様の 外観を呈するためにしばしば問題となる。これは溶融 樹脂合流時に金型表面に拈いて空気や不純物を巻き达 むことによって形成されるV溝が原因である1 ${ }^{1}$.この $\mathrm{V}$ 溝は外観品質の低下をもたらすとともに, とくにポ リスチレンなどのぜい性材料では応力集中による強度 低下の原因となる，黒田らは，表面注じるウェルド ラインの段差量を表面粗さ計で評価した結果, 数 $\mu \mathrm{m}$ の深さであると報告している21. また，筆者らのこれ までの研究によると, 表面のV溝を含む深さ数 100 $\mu \mathrm{m}$ までのウェルドライン領域が成形品強度に影響を 及ぼすとの知見も得ている3)。 
このようなウェルドラインを消去する方法としては, 樹脂温度や金型温度を通常よりも高めに設定すること などが推奖されている4)。 また，八ロゲンランプや高 周波などを用いて成形直前にキャビティを外部から予 熱する方法も発表されている5 ${ }^{5), 6)}$. しかし，これらの 方法には，作業の安全性や成形サイクルなどの点でな お問題が残っており, また, 改善効果の定量的な評価 もこれまであまり行われていない7.

そこで本研究では，金型キャビティに直接固定し たセラミックヒーターを用いて, 射出成形中に会合樹 脂を瞬間加熱することによりウェルドラインを消去す る力法について検討した. この方法には，ウェルドラ インの発生位置を正確に決定してから金型製作をしな ければならない点や複雑な製品に関しては金型製作費 が高くなる点などの短所がある、しかし，金型全体で はなく小型ヒーターのみを瞬時に加熱する方法である ため昇温や降温速度が高く, 成形サイクルーの影響が 少ない利点を持つ、また，特別な外部装置を必要とし ない，ハロダンランプなどが作業環境に与觉る危険性 が少ないなどの長所も持っており, ウェルドライン の効果的な消去方法の一つであると考光られる. 本報 では，ヒーター電圧を変化させた時の外観品質や機械 的強度の変化を測定した。

\section{2. 実験方法}

\section{1 成形材料}

実験に供した成形材料は，沉用のポリスチレン（ダ イアレックス HF-77, 三菱化成ポリテック社製) であ る.メルトインデックスは $7.5 \mathrm{~g} / 10 \mathrm{~min}$ である (JIS K 7200, $200^{\circ} \mathrm{C}$, 荷重 $5 \mathrm{kgf}$ ).

\section{2 金型およびセラミックヒーター}

用いた金型は，Fig. 1 に示すような長方形平板の金 型（長さ $200 \mathrm{~mm} \times$ 幅 $100 \mathrm{~mm} \times$ 厚さ $3 \mathrm{~mm}$ ）である. 2 点ダートなので平板中央部で溶融樹脂が会合しウェ ルドラインが発生する.

斜線で示す部分にセラミックヒーター（京セラ社 製）を取り付けた.これは、シリコンカーバイドなど のセラミックを発熱体とするヒーターとは異なり, ア ルミナを絶縁層として持つ金属発熱体ヒーターである. ヒーターの概略図を Fig. 2 に示す. アルミナシート に金属抵抗体を印刷して，その上にアルミナ絶縁保護 層を塗布して高温で一体焼結したものである.ヒータ 一の全長は $60 \mathrm{~mm}$ で, このうち発熱部の長さは 27 $\mathrm{mm}$ である. 接着剤（アラルダイト LW 561, 長瀬チ バ製）を用いてキャビティ面に直接加工した溝にヒー ターを接着, 固定した。

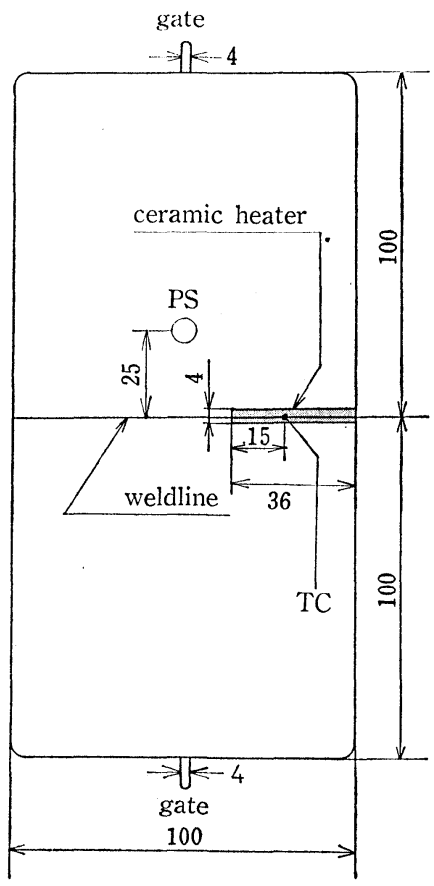

Fig. 1 Injection molded plaque with a weldline at the center

PS : Pressure sensor, TC : Thermocouple.

\section{3 射出成形}

主な射出成形条件を Table 1 亿示す. 射出圧力 $\left(P_{i}\right)$ 性，金型温度が最も低い $30^{\circ} \mathrm{C}$ の時に溶融樹脂 が金型内に充てんされる必要充分な圧力，つまり最 小充填圧力を基準とした. シリンダー温度 $\left(T_{c}\right)$ が $200^{\circ} \mathrm{C}$ の時は $P_{\imath}=125.7 \mathrm{MPa}, 220^{\circ} \mathrm{C}$ の時は $P_{\imath}=$ 99. $4 \mathrm{MPa}$ であった.

ヒーターに直結したスライダックを用いてヒーター 電圧を調節した．Fig. 3 はヒーター電圧とヒーター温 度および金型内圧の時間変化曲線を示している．七ラ ミックヒーターへ通電を開始して一定電圧を加点ると (点A)，温度が上昇しはじめる，温度がほぼ定常に達 したところで射出する (点B). 射出された樹脂が会 合して, ウェルドラインを形成すると同時に樹脂圧力 はピークに達する (点C). この時点でヒーター電圧 を0Vに下げる. キャビティ内のヒーター部温度は溶

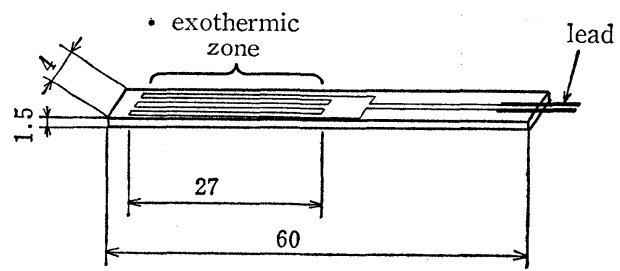

Fig. 2 Schematic drawing of ceramic heater 
Table 1 Molding condition

\begin{tabular}{lccr}
\hline Cylinder Temperature $\left({ }^{\circ} \mathrm{C}\right)$ & & 200 & 220 \\
Mold Temperature $\left({ }^{\circ} \mathrm{C}\right)$ & $30,40,50,60,70,80$ & $30,40,80$ & 40 \\
Injection Pressure (MPa) & 125.7 & $131.7,134.0$ & 99.4 \\
Injection Time (s) & 6 & 5 & 5 \\
Cooling Time (s) & 15 & 25 & 25 \\
Ceramic Heater Voltage (V) & $0,10,15,20,25,30,35,40$ & $0,20,40,60,80,100$ \\
\hline
\end{tabular}

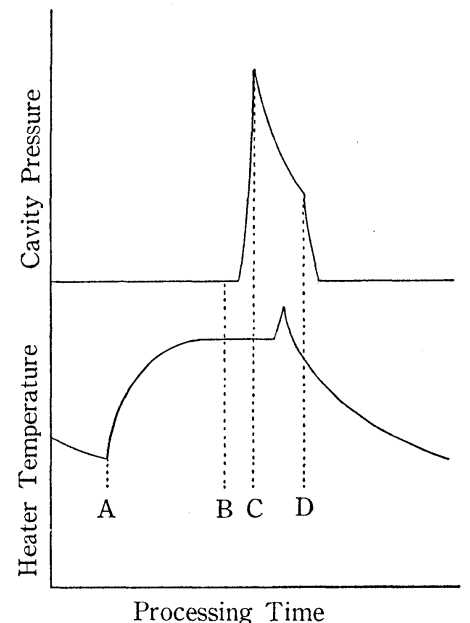

Fig. 3 Heating procedure during injection process ; the upper line indicates cavity pressure and the lower line indicates heater temperature; point $\mathrm{A}=\mathrm{Hea}-$ ter on, $B=$ In jection starts, $C=$ Heater off, $\mathrm{D}=$ Injection stops

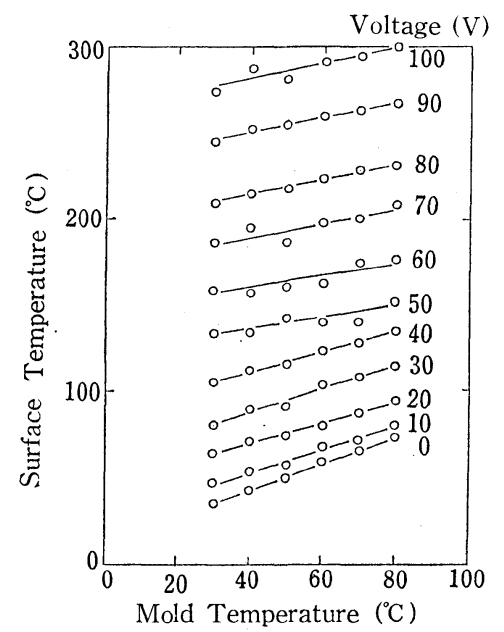

Fig. 5 Relationship between surface temperature of heater and heater voltage at the steady state
Fig. 4

Tensile test specimen cut from injection molding; the weldline remained at the unheated surface was removed using a milling machine

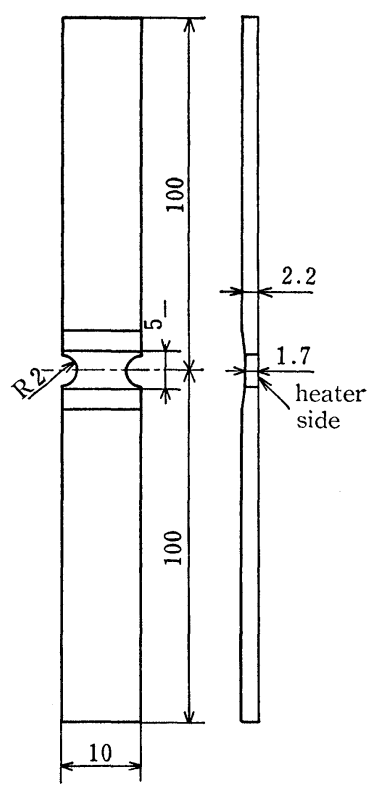

融樹脂の熱により瞬間上昇するもののヒーター電圧が $0 \mathrm{~V}$ のため徐々に低下する，ヒーター温度が低下し始 めた時点で射出を終了する (点 D).

\subsection{SEM 観察と強度試験}

射出成形平板に括けるウェルドラインの改善度合を 評価するために，電子顕微鏡（SEM）を用いてその幅 を測定した。

また，強度を評価するために，平板のウェルド部か ら Fig. 4 飞示す短冊形状の試験片を切り出した. 加 熱側と非加熱側から各 3 本の試験片を作製し, 引張試 験を行った.ヒーターはキャビティの片側側面にのみ 設置されているので，むら一方の側面伐存するV 溝 の 影響を除去するためにフライス盤を用いて約 0.5 $\mathrm{mm}$ の深さで半円状に切削した. 引張試験はインスト ロン引張試験機を用いた．測定条件を以下に示す.

つかみ具間距離 $115 \mathrm{~mm}$, 引張速度 $2 \mathrm{~mm} / \mathrm{min}$, 試 験温度 $23^{\circ} \mathrm{C}$, 湿度 $50 \% \mathrm{RH}$.

\section{3. 結果と考察}

3.1 ヒーター電圧との表面温度

本実験では，セラミックヒーターに一定電圧を加え 
表面温度が定常状態になった時点で樹脂を射出した。 ヒーター表面温度は金型との接着面に取り付けた熱電 対で計測した (Fig. 1 中の TC 点). しかし，この位置 では金型への放熱量が多いため正確な值が得られない, したがって, 熱電対の出力とは別にヒーター電圧とヒ ーター表面温度の関係を較正しなければならない。得 られた補正線図を Fig. 5 に示与。これは, 各金型温 度に和いてヒーターに一定電圧を加えた時のヒーター 部温度を表面温度計で実測して得たるのである，実際 の成形と同様にヒーターを金型に取り付けた状態で測 定を行っているため，金型への放熱の影響が考慮され， 発熱量と放熱量がハシランスした条件下での表面温度が 計测されている．金型温度の上昇にとるない，直線的 に表面温度も上昇している. この温度は, 樹脂が流動 する直前のヒーター温度に相当する.

\section{2 金型温度とウェルドライン幅}

金型温度とウェルドライン幅の関係をFig. 6 に示 す. 金型温度を $30 \sim 80^{\circ} \mathrm{C}$ の間で変化させた時のウェ ルドライン幅の変化を示している. は加熱部（七ラ ミックヒーターの中央位置), ○は非加熱部 (ヒータ 一から $4 \mathrm{~mm}$ 離れた位置) の测定結果である. 非加熱 部では, 金型温度 $30^{\circ} \mathrm{C}$ ではウェルドライン幅は約 $17 \mu \mathrm{m}$ だが，金型温度が上がるにしたがって急激に減 少した、金型温度を高めるだけですウェルドライン消 去に効果があることがわかる，加熱部でも同様に金型 温度の效果がみられたが，非加熱部と較べると約 5 $\mu \mathrm{m}$ 小さいウェルドライン幅となった. これは, 素材 の伝熱特性の違いによるものと考光られる. 七ラミッ
Fig. 6

Influence of mold temperature on weldine width;

2. : unheated area, $\bigcirc$ : heated area

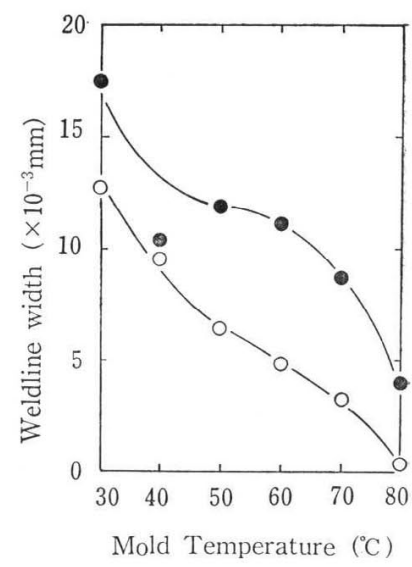

クヒーターの主成分であるアルミナの熱伝導率は, 金 型に用いられる炭素鋼に比べて若干小さく，断熱効果 が高いと考光られる8). したがって，たとえヒーター 加熱しない場合でも，ヒーターに接触した部分の樹脂 は融着が充分となり，結果的にウェルドライン幅が小 さくなる.このよらに, 金型表面の熱伝導率を下げる こともウェルドライン消去に効果があると思われる. 金型温度 $80^{\circ} \mathrm{C}$ 以上ではウェルドライン幅はどの場合 もほとんど $0 \mu \mathrm{m}$ となった。

\section{3 ヒーター加熱法によるウェルドライン幅の 变化}

次にヒーター電圧が $0 \sim 100 \mathrm{~V}$ と広範囲に変化させ た時のウェルドライン幅の変化を調べた. Fig. 7 に示 す SEM 写真はヒーターから $4 \mathrm{~mm}$ 離れた非加熱部

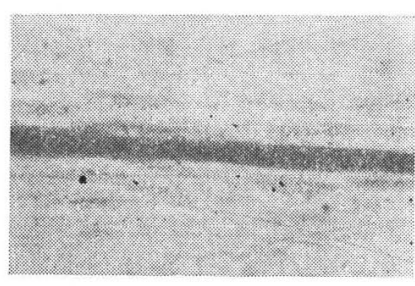

(a)

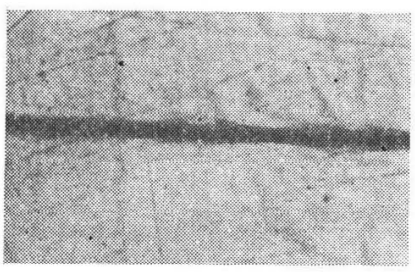

(d)

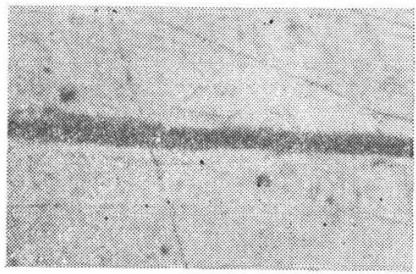

(b)

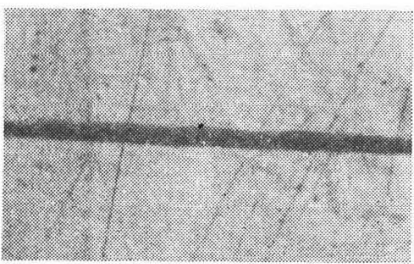

(e)

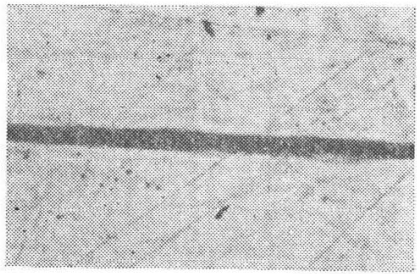

(c)

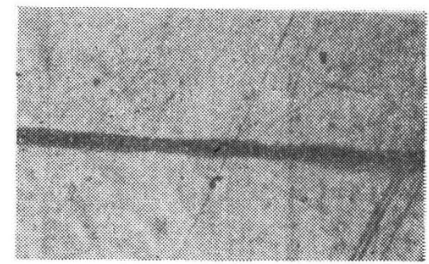

(f)

Fig. 7 SEM micrographs of weldline in the unheated area, Ceramic heater voltage: (a) 0 , (b ) 20 , (c ) 40 , (d) 60 , (e) 80 , (f) $100 \mathrm{~V}$ 


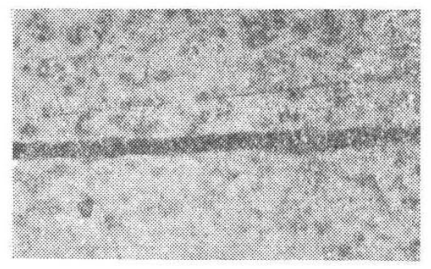

(a)

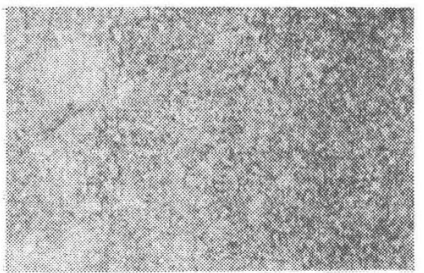

(d)

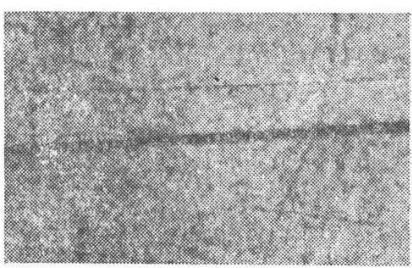

(b)

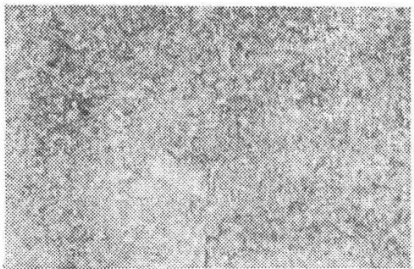

(e)

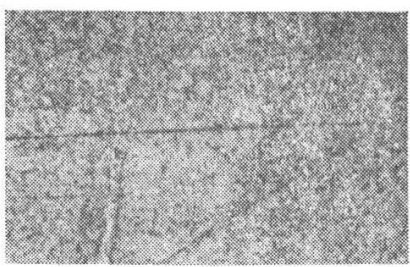

(c)

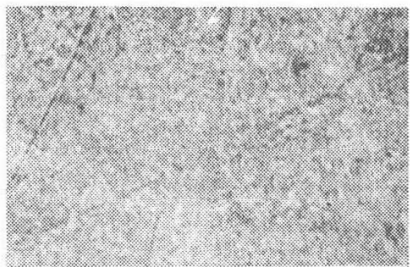

(f)

Fig. 8 SEM micrographs of weldline in the heated area, Ceramic heater voltage: (a) 0 , (b) 20 , (c ) 40 , (d) 60 , (e) 80 , (f) $100 \mathrm{~V}$

のウェルドラインである.ウェルドラインは黑い帯状 の線として観察された. 電圧 $0 \mathrm{~V}$ の時のウェルドライ ン幅は $23 \mu \mathrm{m}$ だが，電圧を上げても，その幅は臣と んど変化しなかった。これより，七ラミックヒーター は，ヒーターに接触する樹脂だけを加熱し，その他部 分には全く影讋を及ぼさないことがわかる．Fig.8は ヒーター加熱部に执ける同様の SEM 写真である。電 圧 $0 \mathrm{~V}$ の時のウェルドライン幅は $21 \mu \mathrm{m}$ であり, 非

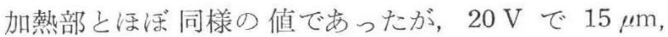
$40 \mathrm{~V} て 5.5 \mathrm{~m}$ と次第に小さくなり，60V 以上では完 全に外観上除去された.

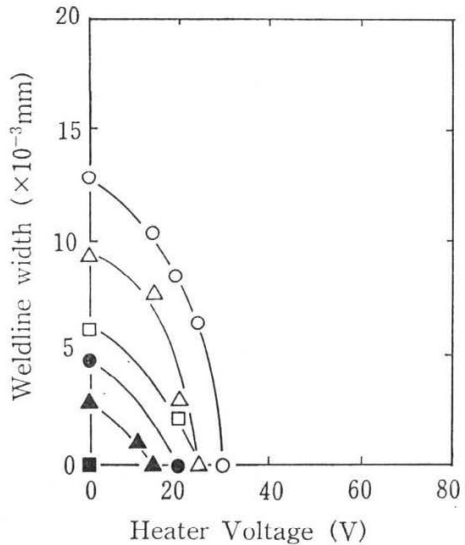

Fig. 9 Relationship between heater voltage and weldline width (heated area); mold temperature $\bigcirc: 30, \triangle: 40, \square: 50, \quad: 60$, A : 70 , 国: $80^{\circ} \mathrm{C}$
ウェルドライン周辺では表面状態は電圧の上昇にし たがって粗面に变化している. これは表面転写性の向 上によってヒーター表面の微細な凹凹が転写されたた めである.より外観品質を向上させるためにはヒータ 一表面の研摩, あるいはめっき処理などが必要になる と思われる。

$80 \mathrm{~V}$ 以上の高電压下では, とくに表面状態が悪化 するので, 実用上効果的と思秃わる $40 \mathrm{~V}$ 以下の範䧃 に関して，種々の金型温度条件 $\left(30 \sim 80^{\circ} \mathrm{C}\right)$ に捛汀る ヒーター電压とウェルドライン幅の関係学検討した。 結果を Fig. 9 に示す。.やはり，金型温度が低い淁ど

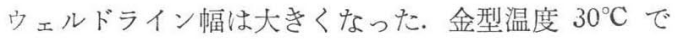

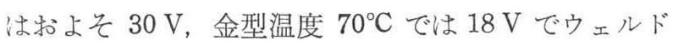
ライン幅が 0 になり, ウェルドラインは完全に表面か ら消去することがわかった. Fig. 3 に示した較正線図 によってウェルドラインが消失したときのヒーター電 压から表面温度を求めると，持よと $80^{\circ} \mathrm{C}$ となった。 これは，ポリスチレンのガラス転移点 $\left(80 \sim 100^{\circ} \mathrm{C}\right)$ に相当する温度である. 一方, 非加熱部では Fig. 10 に示すよらに, 金型温度が低い場合に若干幅の変動が 大きくはあるが，その平均值は電圧を上げてもほとん ど変化して拉らず，ウェルドラインの解消は認められ なかった。

\section{4 ヒーター加熱とウェルド強度}

ヒーター電压に詨するウェルド強度变化を Fig. 11 に示す. ○拈よ゙ $\triangle$ は, 各々, 射出圧力 $P_{i}=131.7$, 134. $0 \mathrm{MPa}$, かつシリンダ温度 $T_{c}=200^{\circ} \mathrm{C}$ の場合を,

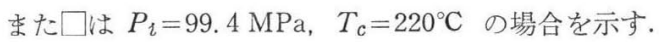




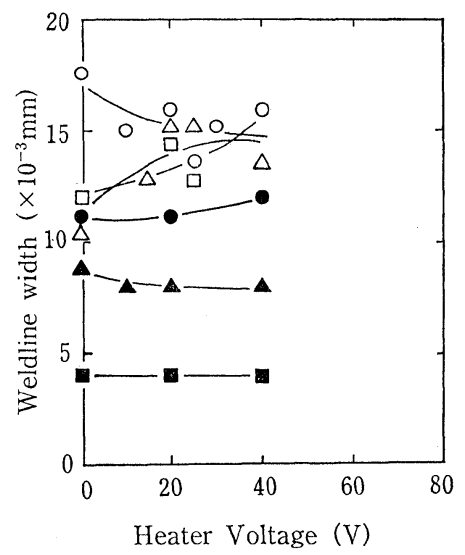

Fig. 10 Relationship between heater voltage and weldline width (unheated area); the symbols are the same as those in Fig. 9

どの成形条件下でも，ヒーター電圧の増加に対してウ ェルド強度は約 $30 \mathrm{MPa}$ と一定であった. ダンベル試 験片を用いたこれまでの筆者らの研究に执いて，尔り スチレン射出成形品のウェルドラインを機械的に切削 除去した時のウェルド強度は約 $35 \mathrm{MPa}$ であった2). 成形品形状や成形条件が異なるため厳密な比較はでき ないが，本論で検討したヒーター加熱法では，ウェル ドラインを機械的に除去した場合よりも低い強度にし か達しなかった.このことから，以下のような状態が 考察される.

ヒーター加熱法によって樹脂の融着が促進され，表 面のV溝は除去される。 しかし，外観不良が改善され ても表面の分子鎖の絡み合い度はとれほど向上しなか ったために，この領域が切り久き効果を発揮して，ウ ェルド強度はあまり向上しなかったと推察される、ま た，加熱部樹脂に白化現象が見られたことなどから， ヒータ一加熱法が不均一冷却を招いて成形品中に成形 ひずみが生じたことも考えられ，これらの理由で強度 が期待した注ど改善されなかったと思われる。

\section{4. 結 言}

射出成形品に生じるウェルドラインの解決方法とし て，成形中にヒーターを用いて樹脂を加熱する方法を 検討した，その結果，ヒーターにより合流時の溶融樹 脂を部分加熱することによってウェルドラインが消去 されることがわかった，ヒーター電圧が高いほどウェ

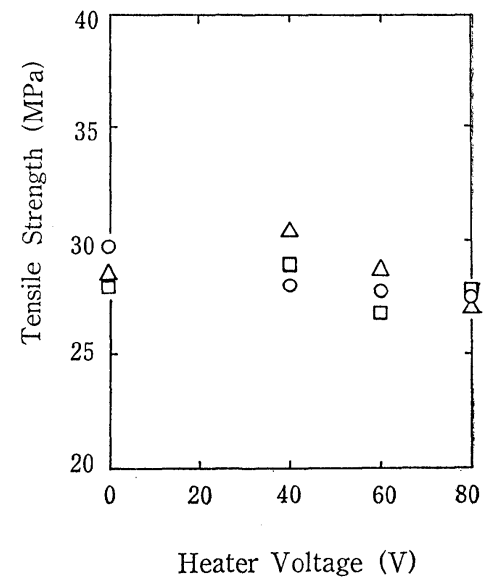

Fig. 11 Effect of heater voltage on the tensile strength; mold temperature $40^{\circ} \mathrm{C}, \bigcirc: T_{c}=200$ ${ }^{\circ} \mathrm{C}, \quad P_{i}=131.7 \mathrm{MPa}, \quad \triangle: T_{c}=$ $200^{\circ} \mathrm{C}, P_{i}=134.0 \mathrm{MPa}, \square: T_{c}=$ $220^{\circ} \mathrm{C}, P_{i}=99.4 \mathrm{MPa}$

ルドライン幅は小さくなり, 非加熱の場合に比べて大 幅に改善された. しかし，外観品質は向上したにも関 わらず，ウェルド強度は泀とんど改善されなかった。 これは，表面のV 溝が消去されても成形品内部には分 子鎖の絡み合いが不足した低融着領域が存在するため と考学られる，また，局部加熱による内部ひずみ発生 の可能性もあり, 実用化のためにはさらに詳細な検討 が必要である.

\section{参 考 文 献}

1) Hagerman, E. M.: Plast. Eng., 29, 67 (1973)

2）黑田英夫，下平勝義：成形加工，2，（2），159 (1990)

3) Tomari, K., Tonogai, S., Harada, T., Hamada, H., Lee, K., Morii, T. and Maekawa, Z. : Polym. Eng. Sci., 30, 931 (1990)

4) 中原靖幸 : プラスチック加工技術便覧（編集委員 会編)：177(1976)，日刊工業新聞社

5）尾浦正幸，木原武久，上田誠一：Moulding，13， (2)，4 (1989)

6) 和田明紘, 川端繁忠 : 成 形加工, 3(2)，165 (1991)

7）割野孝一, 田村 弘, 松丸重雄 : 第 2 回プラスチ ック成形加工学会予稿集, p. 207 (1990)

8）熱物性ハンドブック（日本熱物 性 学会編), 188 (1990)，養賢堂 